\title{
Response of Deep-Sea Macrobenthos to a Small-scale Environmental Disturbance
}

\author{
B. S. Ingole*, Z. A. Ansari, V. Rathod \& N. Rodrigues \\ National Institute of Oceanography, \\ Dona Paula, Goa - 403004.
}

\begin{abstract}
To assess the possible effect of nodule mining on deep-sea environment, the Indian Deep-sea Environment Experiment (INDEX) was undertaken in the Indian Basin. The present investigation is a part of the disturbance and recolonization study. Pre- and post-disturbance sediment samples were collected from 21 stations between $10^{\circ} 01^{\prime}-10^{\circ} 03^{\prime} \mathrm{S}$ and $75^{\circ} 59^{\prime}-76^{\circ} 02^{\prime} \mathrm{E}$ at water depths of $5300-5350 \mathrm{~m}$ to assess the effect of benthic disturbance. There was a significant change in the composition and biomass of macrofauna after the disturbance. Post-disturbance vertical profiles indicated a $63 \%$ reduction in the numerical count in the top 0-2-cm layer and high aggregation of macrofauna in deeper $(5-10-\mathrm{cm})$ sediment layer. The impact of the disturbance was severe, as the mean biomass of macrofauna was significantly reduced in the disturbed area, probably due to the displacement and /or mortality caused by the benthic disturber.
\end{abstract}

Keywords: Environmental disturbance, benthic fauna; Impact assessment; Central Indian Basin.

*Corresponding author: Fax: 091 (832) 223340;email : baban@csnio.ren.nic in 


\section{Introduction}

The deep-sea floor of the Central Indian Basin (CIB) is known to harbour a remarkable benthic biodiversity (Neymann et al. 1973; Parulekar et al. 1982;1992 Ingole et al. 1992; Ansari et al. 1996 Ingole et al. 1999; Ansari, 2000; Ingole et al. 2000). However, there is very little information on deep-sea benthos of this area in relation to environmental parameters. As compared to the coastal and shallow sub-tidal benthic environment, temperature, salinity and dissolved oxygen fluctuate within a very narrow range at abyssal depths, where food availability is limited (Pfanukuche, 1993). While describing the standing stock of deep-sea benthos Watts et al (1992) and Ingole et al (1992) demonstrated direct relationship between benthic biomass and surface pigment biomass. In the deep-sea environment such as CIB, the production of sediment organic matter is low (Nath \& Mudholkar, 1989) and hence benthic biota has to rely on the particulate organic matter that is produced in the euphotic zone. The benthic community has presumably adapted to the prevailing conditions at deep-sea and any disturbance to their environment will certainly bring major changes in the composition and abundance of benthos (Thistle et al. 1985; Foell et al. 1990).

It is assumed that when an artifical disturbance is created on the seabed, the surface layers of the sediment in the upper few centimeters is disturbed, which could lead to changes in the existing depositional and decompositional biota-sediment processes. Thus, deep-sea mining operations will potentially produce some undesirable environmental effects, both in the water column and on the seabed (Berge et al. 1991; Thiel et al. 1992). Possible effects are expected to involve biochemical changes resulting in biotic responses (Raghukumar et al. 2001) as well as direct impacts on organisms (Bluhm, 1994;1999; Shirayama, 1999; Ingole et al. 1999). Although commercial mining of nodules from the deep sea may take a few decades, the potential impacts need to be studied in advance. In this respect the results obtained from the environmental impact studies conducted in the coastal areas (Roberts et al.1998; Harvey et al. 1998) can be used for better understanding and maintaining the ecological balance in the deep-sea benthic environment.

To assess the possible impact of nodule mining on the benthic environment, Indian Deep-sea Environment Experiment (INDEX) was conducted in the Central Indian Basin (CIB). This experiment comprised of baseline and pre-disturbance study, physical disturbance of the sea bottom, and post-disturbance study. In this investigation, we have compiled and presented data on effect of disturbance on macrobenthos collected during pre-and post-disturbance study. The hypothesis we have tested here is that benthic disturbance will reduce the benthic population.

\section{Materials \& Methods}

The sediment samples for the present study were collected from a total of 21 stations ( 6 predisturbance, 15 post-disturbance) distributed in the CIB. The experiment site lies between $10^{\circ} 01^{\prime}$ 
- 10 $03^{\prime} \mathrm{S}$ and $75^{\circ} 59^{\prime}-76^{\circ} 02^{\prime} \mathrm{E}$, with a 5300 - $5350 \mathrm{~m}$ depth range (Table 1). A strip $3000 \mathrm{~m}$ long and $200 \mathrm{~m}$ wide oriented in a NW-SE direction was selected for the disturbance experiment (Fig.1). Box core (50x50x50-cm size) samples were analysed in the present study. Sub-samples for macrofauna were taken with an 8-cm diameter plastic core tube. The sediment was sectioned at $0-2,2-5,5-10$, and $10-20-\mathrm{cm}$. A replicate sample was taken at each station, and all samples were preserved in $10 \%$ formalin Rose bengal solution. Faunal components were identified only to the group /order level.

\section{Results}

Composition and abundance of macrofauna : Abundances of macrofauna in the CIB area are given in Table 2-3. The average density and biomass recorded down to a depth of 20-cm ranged from 48 to 704 individuals $\mathrm{m}^{-2}$ (mean \pm SD; $336 \pm 463.7, \mathrm{n}=6$ ) and 4.6 to $69.3 \mathrm{mg} \cdot \mathrm{m}^{-2}$ (mean $\pm \mathrm{SD}$; $24.1 \pm 25.5, n=6$ ) during the pre-disturbance (Fig. 2). The values for post-disturbance showed wide fluctuations, mainly due to the emergence of larger forms such as holothurians and bivalves. The values ranged from 32 to 1120 individuals $\mathrm{m}^{-2}$ (mean $\pm S D ; 391.7 \pm 512.2, \mathrm{n}=15$; Fig.2) and 1.6 to $246 \mathrm{mg} \cdot \mathrm{m}^{-2}$ (mean $\pm \mathrm{SD} ; 85.3 \pm 79.9, \mathrm{n}=15$ ). A total of 17 macrofaunal groups were recorded from the CIB area (Table 2-3).

The community structure of the study area was dominated by polychaetes (bristle worms), which constituted $65 \%$ of the total population in pre-disturbance sediments. Next in the order of abundance were crustaceans $(31.8 \%)$, which included various small but prominent peracarid forms such as Tanaidacea, Isopoda, Amphipoda and Cumacea. The other taxa included Mollusca (1.5\%) and Sipunculida (1.4\%). Taxonomic composition of the macrofaunal community in the post-disturbance samples indicated the dominance of nematodes (33\%), crustaceans $(28 \%)$ and polychaetes $(27 \%)$. Small crustaceans, such as cumaceans and harpacticoid copepods, were abundant in most of the samples. Bivalves, gastropods and holothurians were also abundant in few samples and accounted for $12 \%$. A close scrutiny of the numerical abundance after physical disturbance suggested no significant change in the density of macrofauna outside the disturbance track, while a significant reduction in the numerical count was recorded inside the disturbance track ( $t$ test, $t=1.0069 ; p=0.3475, d f=6$ ). A comparison of macrofaunal taxa during pre- and post-disturbance suggested significant deviation in major taxa (Fig. 3). Data on the biomass (wet weight) of pre-disturbance (6 stations) were compared with post-disturbance, it showed significant difference ( $t$ test, $t=1.943, p<0.07, d f=5$ ).

Vertical Distribution of Macrofauna: The vertical distribution of macrobenthos showed that the majority of the benthic animals were concentrated in the upper $0-5-\mathrm{cm}$ layers during the predisturbance study (Fig. 4), with maximum density (61\%) in the top 0-2-cm layer (Table 4). Only polychaetes and bivalves were recorded in the deeper layers $(10-20-\mathrm{cm})$. The crustaceans, being epibenthic and detritivores, were restricted to the top 5-cm layers of the sediment. This picture 
changed somewhat in the post-disturbance samples (Table 4). Polychaetes and crustaceans (isopods) were present in all cores in the post-disturbance samples, but their composition was drastically reduced in the top $0-2-\mathrm{cm}$ sediment layer (Table 4). The emergence of small epibenthic crustaceans such as Cumacea and Isopoda was conspicuous. The abundances of Gastropoda, Bivalvia, Ostracoda and Holothuroidea increased dramatically during the postdisturbance (Fig. 3). The vertical profile indicated high aggregations of macrofauna in much deeper $(5-10-\mathrm{cm})$ layers and almost $63 \%$ reduction in the top $0-2-\mathrm{cm}$ sediment layer during the post-disturbance (Fig. 4).

\section{Discussion}

Polychaetes generally have been found to be dense in the deep-sea benthic environment (Gage, 1978; Parulekar et al. 1982; Ingole et al. 1992). This trend also was observed in the present study, with crustaceans coming second in abundance particularly after disturbance. The vertical profile showed aggregation of macroinvertebrates in the top $0-5-\mathrm{cm}$ in pre-disturbance. This picture completely changed during the post-disturbance particularly in the top 0-2-cm sediment layer (Fig.4). The numbers generally decreased in the disturbance track, while outside the track there was marginal increase in the mean density of macrofauna (Fig. 2). It is believed that the sediment disturbance at deep-sea level is deleterious to the buried in-fauna; however, disturbance also increases the food resources for larger benthic animals by exposing the organicrich sediment to the surface (Bluhm, 1994). During post-disturbance, many organisms of the top layer may either die or get carried to other areas. Since the post-disturbance study was conducted immediately after the disturbance, the number of animals outside the track could increase further with time.

As the quantity of the available food at the abyssal depths is considered an important factor determining the deep-sea benthic standing stock (Thiel et al. 1989, Pfannkuche,1993), the vertical profile of sediment organic carbon in CIB also was studied (Anon, 1997). It was suggested that the high concentration of organic carbon in deep sediment layer, could be due to the presence of refractory fraction of organic matter left after the carbon mineralization (Anon, 1997). Significant increase in the sediment organic carbon in top 0-2-cm sediment layer during post-disturbance was due to the shifting of organic-rich deeper sediment to the surface (Ingole et al. 1999). Therefore, the operation of disturber at deep-sea may actually enhance the food supply to the benthic organisms by altering the sediment layers (similar to the large-scale bioturbation process).

While comparing the vertical distribution of metazoan meiofauna during pre-and post-disturbance, Ingole et al (1999) reported significant reduction in the abundance of meiofauna with no obvious change in composition. In the present case, not only the macrofaunal abundance was changed during post-disturbance but also the community composition was affected. The polychaetes, 
which are normally dominant in the deep-sea environment, were replaced by smaller crustaceans (Cumacea and Harpacticoida) and nematodes during post-disturbance. This was evident particularly in the top 0-2 cm sediment layer (Table 4). The significant reduction in macrobenthic population on the disturbance track (in top $0-2-\mathrm{cm}$ layer) could be due to the mortality of epifaunal organisms that are exposed to the predators after disturbance. Secondly, the possibility of mobile macro- and megafauna moving to other undisturbed areas cannot be ruled out. This statement is supported by our observation on the biomass distribution. Increased macrobenthic biomass during post-disturbance and its significant variation (Two-way ANOVA, $F=3.352 ; p<0.1$; $\mathrm{n}=5$ ) from pre-disturbance data (Fig. 2) clearly suggests the movement of larger mobile forms to the nearby-undisturbed area. Thus, the impact of the disturbance was severe as the mean biomass of macrofauna was significantly reduced (52\% reduction) in the disturbed area, probably due to the displacement and /or mortality caused by the benthic disturber. However, the changes in benthic community observed here should be considered at macro level only because the sampling for post-disturbance was conducted immediately (i.e., < 2-months of disturbanceexperiment), and the finer changes after resettlement of the disturbed sediment have not yet been monitored. Nevertheless, the impact of the disturbance was significant on the benthic macrofauna.

\section{Acknowledgements}

The authors are thankful to the scientists, officers and crew of research vessel SGE Yuzhmorgeologiya for help in on board sample collection. The authors also thank Ms.Caroline Castalino for laboratory assistance. This study was carried out as a part of 'Environmental Imapct Assessment of nodule mining in Central Indian Basin' funded by Dept. of Ocean Development (Govt. of India). This is contribution No.3659 of NIO, Goa. 


\section{References:}

Anon, 1997. Benthic disturbance and impact studies - phase II of Environmental Impact Assessment for nodule mining, INDEX. Tech. Rep. NIO, Goa, India.

Ansari, Z. A., 2000. Distribution of Deep-sea Benthos in INDEX area. Marine Georesources \& Geotechnology 18(3),

Ansari, Z. A., Ingole, B. S., Parulekar, A. H., 1996. Benthos of the EEZ of India. In:Qasim S.Z., Roonwal G.S. (Eds.), India's Exclusive Economic Zone- Resource Exploitation, Management. Omega Scientific Pub. New Delhi, 74-86 pp.

Berge, S., Markussen, J. M., Vigerust, G.,1991. Environmental consequences of deep seabed mining. Problem Areas and Regulations. Ocean Mining Series, The Fridtjof Nansen Institute Oslo, Norway, 135 pp.

Bluhm, H., 1994. Monitoring megabenthic communities in abyssal manganese nodule sites of the east Pacific Ocean in association with commercial deep-sea mining. Aquatic Conservation: Marine and Freshwater Ecosystems 4,187-201.

Bluhm, H.,1999. Holothurians as indicators for recolonisation processes in environmental assessment. Proceeding of III ISOPE - Ocean Mining Symposium, NIO, Goa, 177-184 $\mathrm{pp}$.

Foell, E.J, Thiel, H., Schriever, G., 1990. Along term, large scale disturbance recolonization experiment in the abyssal eastern tropical South Pacific Ocean. Proceeding $22^{\text {nd }}$ annual Offshore Technology Conference, Houston, Texas USA, 497-503 pp.

Gage, J. D.,1978. Animals in deep-sea sediments. Proceeding Royal Society of Edinburgh 768,77-93 pp.

Harvey, M.,Gauthier, D., Munro, J., 1998. Temporal changes in the composition and abundance of the macro-benthic invertebrate communities at dredged material disposal sites in the Anse a Beaufils, Baie des Chaleurs, Eastern Canada. Marine Pollution Bulletin 36 (1):41-55.

Ingole, B. S., Ansari, Z. A., Parulekar, A. H.,1992. Benthic fauna around Mauritius Island, southwest Indian Ocean. Indian Journal of Marine Science 21,268-273.

Ingole, B. S., Ansari, Z. A., Matondkar, S. G. P., Rodrigues, N., 1999. Immediate Response of Meio and Macrobenthos to disturbance caused by a benthic disturber. Proceedings of III ISOPE - Ocean Mining Symposium NIO, Goa, 191-197 pp.

Ingole, B. S., Ansari, Z. A., Rathod, V., Rodrigues, N., 2000. Effect of benthic disturbance on the distribution of meiofauna In the Central Indian Ocean. Marine Georesources \& Geotechnology 18(3),

Nath, B. N., Mudholkar, A. V., 1989. Early diagenetic processes affecting nutrients in the pore waters of Central Indian Ocean Cores. Marine Geology 86 (1), 5766.

Neymann, A. A., Sokolova, M. N., Vinogradova, N. G., Pasternak, F. A., 1973. Some pattern in the distribution of bottom fauna in the Indian Ocean. In:Zeitschel B. (Ed.), The Biology of the Indian Ocean (Ecological studies 3) . Springer-Verlag, Berlin, 467-473 pp.

Parulekar, A.H., Harkantra, S. N., Ansari, Z. A., Matondkar, S. G. P., 1982. Abyssal benthos of the central Indian Ocean. Deep-sea Research 29, 1531-1537. 
Parulekar. A. H., Ingole, B. S., Harkantra, S. N., Ansari, Z. A., 1992. Deep-sea benthos of the western and central Indian Ocean. In: Desai B.N.(Ed.), Oceonography of the Indian Ocean Oxford Pub., New Delhi, 261-267 pp.

Pfannkuche, O., 1993. Benthic response to the sedimentation of particulate organic matter at the BIOTRANS station, $47^{\circ} \mathrm{N}, 20^{\circ} \mathrm{W}$. Deep-sea Research II 40, 135-149.

Raghukumar, C., Lokabharathi, P.A., Ansari, Z. A., Nair, S., Ingole, B. S., Sheelu, G., Mohandass, C., Nath, B. N., Rodrigues, N., 2001. Bacterial standing stock, meiofauna and sediment nutrient characteristics: indicators of benthic disturbance in the Central Indian Basin. Deep-Sea Research, II (in this issue).

Roberts, R., Gregory, M. R., Foster, B. A., 1998. Developing an efficient macrofauna monitoring index from an impact study- A dredge spoil example. Marine Pollution Bulletin 36 (3), 231-235.

Shirayama, Y., 1999. Biological results of the Jet Project: An overview. Proceedings of III ISOPE Ocean Mining Symposium NIO, Goa, 185-190 pp.

Thiel, H., Pfannkuche, O., Schriever, G., Lochte, K., Gooday, A. J., Hemleben, Ch., Mantoura, R. F. G., Turley, C. M., Patching, J. W., Riemann, F., 1989. Phytodetritus on the deep-sea floor in a central oceanic region of the Northeast Atlantic. Biological Oceanography 6, 203-239.

Thiel, H., Foell, E. J., Schriever.G., 1992. Potential Environmental Effects of Deep-sea Mining, University of Hamburg, 214 pp.

Thistle, D., Yingst, J. Y., Fauchald, K., 1985. A deep-sea benthic community exposed to strong near bottom current on the Scotian Rise (Western Atlantic). Marine Geology 66, 91-112.

Watts, M.C., Etter, R.J.,Rex, M. A., 1992. Effect of spatial and temporal scale on the relationship of surface pigment biomass to community structure in the deep-sea benthos. In: Rowe G.T., Pariente V. (Eds.) Deep-Sea Food Chains and the Global Cycle. Kluwer Academic Pub. 245-254 pp. 
Table 1: Details of the box corer sampling in the Central Indian Ocean.

\begin{tabular}{|c|c|c|c|c|}
\hline $\begin{array}{c}\text { Station } \\
\text { No. }\end{array}$ & $\begin{array}{c}\text { Samplin } \\
\text { g Date }\end{array}$ & $\begin{array}{l}\text { Depth } \\
(\mathrm{m})\end{array}$ & \multicolumn{2}{|c|}{ Geographical position } \\
\hline \multicolumn{3}{|c|}{ Pre-disturbance } & Latitude (S) & Longitude (E) \\
\hline $\mathrm{BC}-11$ & 24.6 .97 & 5330 & \begin{tabular}{|l}
$10^{\circ} 02^{\prime} 058^{\prime \prime}$ \\
\end{tabular} & $76^{\circ} 01^{\prime} 332^{\prime \prime}$ \\
\hline BC-12 & 24.6 .97 & 5320 & $10^{\circ} 01^{\prime} 373^{\prime \prime}$ & $76^{\circ} 00^{\prime} 610^{\prime \prime}$ \\
\hline $\mathrm{BC}-13$ & 25.6 .97 & 5320 & $10^{\circ} 01^{\prime} 512^{\prime \prime}$ & $76^{\circ} 00^{\prime} 328^{\prime \prime}$ \\
\hline $\mathrm{BC}-15$ & 26.6 .97 & 5330 & $10^{\circ} 02^{\prime} 408^{\prime \prime}$ & $76^{\circ} 00^{\prime} 027^{\prime \prime}$ \\
\hline BC-16 & 28.6 .97 & 5330 & $10^{\circ} 02^{\prime} 593^{\prime \prime}$ & $76^{\circ} 00^{\prime} 940^{\prime \prime}$ \\
\hline BC-17 & 30.6 .97 & 5300 & \begin{tabular}{|l|}
$10^{\circ} 02^{\prime} 090^{\prime \prime}$ \\
\end{tabular} & $76^{\circ} 00^{\prime} 762^{\prime \prime}$ \\
\hline \multicolumn{5}{|c|}{ Post-disturbance } \\
\hline BC-02 & 22.8 .97 & 5320 & $10^{\circ} 02^{\prime} 313^{\prime \prime}$ & $76^{\circ} 01^{\prime} 067^{\prime \prime}$ \\
\hline $\mathrm{BC}-03$ & 22.8 .97 & 5320 & $10^{\circ} 02^{\prime} 056^{\prime \prime}$ & $76^{\circ} 00^{\prime} 569^{\prime \prime}$ \\
\hline BC-04 & 21.8 .97 & 5320 & $10^{\circ} 01^{\prime} 498^{\prime \prime}$ & $75^{\circ} 59^{\prime} 680^{\prime \prime}$ \\
\hline BC-05 & 20.8 .97 & 5320 & $10^{\circ} 01^{\prime} 787^{\prime \prime}$ & $76^{\circ} 00^{\prime} 122^{\prime \prime}$ \\
\hline BC-06 & 23.8 .97 & 5320 & $10^{\circ} 02^{\prime} 643^{\prime \prime}$ & $76^{\circ} 01^{\prime} 820^{\prime \prime}$ \\
\hline BC-07 & 26.8 .97 & 5330 & $10^{\circ} 02^{\prime} 313^{\prime \prime}$ & $76^{\circ} 00^{\prime} 470^{\prime \prime}$ \\
\hline $\mathrm{BC}-11$ & 25.8 .97 & 5330 & $10^{\circ} 02^{\prime} 105^{\prime \prime}$ & $76^{\circ} 01^{\prime} 236^{\prime \prime}$ \\
\hline $\mathrm{BC}-12$ & 23.8 .97 & 5320 & $10^{\circ} 01^{\prime} 382^{\prime \prime}$ & $76^{\circ} 00^{\prime} 591^{\prime \prime}$ \\
\hline BC-13 & 23.8 .97 & 5320 & $10^{\circ} 01^{\prime} 522^{\prime \prime}$ & $76^{\circ} 00^{\prime} 341^{\prime \prime}$ \\
\hline BC-14 & 25.8 .97 & 5330 & $10^{\circ} 02^{\prime} 172^{\prime \prime}$ & $76^{\circ} 00^{\prime} 120^{\prime \prime}$ \\
\hline BC-15 & 27.8 .97 & 5330 & $10^{\circ} 02^{\prime} 172^{\prime \prime}$ & $76^{\circ} 00^{\prime} 012^{\prime \prime}$ \\
\hline $\mathrm{BC}-16$ & 26.8 .97 & 5330 & $10^{\circ} 02^{\prime} 606^{\prime \prime}$ & $76^{\circ} 00^{\prime} 947^{\prime \prime}$ \\
\hline BC-18 & 28.8 .97 & 5320 & $10^{\circ} 02^{\prime} 729^{\prime \prime}$ & $76^{\circ} 00^{\prime} 613^{\prime \prime}$ \\
\hline BC-19 & 27.8 .97 & 5320 & $10^{\circ} 02^{\prime} 173^{\prime \prime}$ & $76^{\circ} 00^{\prime} 819^{\prime \prime}$ \\
\hline BC-20 & 26.8 .97 & 5300 & $10^{\circ} 01^{\prime} 925^{\prime \prime}$ & $76^{\circ} 00^{\prime} 347^{\prime \prime}$ \\
\hline
\end{tabular}


Table 2: Composition and abundance of macrofauna (mean nos. $\mathrm{m}^{-2}$ ) in CIB studied during INDEX (Pre-disturbance) cruises.

\begin{tabular}{|l|l|c|c|c|c|c|c|c|}
\hline & & \multicolumn{7}{|c|}{ Stations } \\
\hline $\begin{array}{l}\text { Depth } \\
(\mathrm{cms})\end{array}$ & Taxa & 11 & 12 & 13 & 14 & 15 & 16 & Mean \pm sd \\
\hline $0-2$ & Polychaeta & 80 & 80 & 32 & 128 & 32 & 32 & $64.0 \pm 39.2$ \\
\hline & Harpacticoida & 80 & 80 & 0 & 16 & 16 & 0 & $32 \pm 37.9$ \\
\hline & Tanaidacea & 32 & 32 & 0 & 0 & 16 & 16 & $16.0 \pm 14.3$ \\
\hline & Nematoda & 16 & 336 & 16 & 48 & 0 & 48 & $77.3 \pm 128.2$ \\
\hline & Sipunculida & 0 & 32 & 0 & 0 & 0 & 0 & $5.3 \pm 13.1$ \\
\hline & Oligochaeta & 16 & 0 & 0 & 0 & 0 & 0 & $2.7 \pm 6.5$ \\
\hline & Unidentified & 0 & 32 & 0 & 0 & 0 & 0 & $5.3 \pm 13.1$ \\
\hline $2-5$ & Polychaeta & 0 & 0 & 0 & 0 & 32 & 32 & $10.7 \pm 16.5$ \\
\hline & Harpacticoida & 32 & 0 & 0 & 0 & 0 & 16 & $8.0 \pm 13.4$ \\
\hline & Tanaidacea & 0 & 0 & 0 & 0 & 16 & 0 & $2.7 \pm 6.5$ \\
\hline & Nematoda & 0 & 32 & 0 & 48 & 0 & 0 & $13.3 \pm 21.3$ \\
\hline $5-10$ & Polychaeta & 48 & 0 & 0 & 16 & 32 & 16 & $18.7 \pm 18.7$ \\
\hline & Harpacticoida & 0 & 0 & 0 & 0 & 48 & 32 & $13.3 \pm 21.3$ \\
\hline & Tanaidacea & 0 & 0 & 0 & 16 & 32 & 0 & $8.0 \pm 13.3$ \\
\hline & Nematoda & 32 & 0 & 0 & 32 & 16 & 0 & $13.3 \pm 15.7$ \\
\hline $10-20$ & Polychaeta & 0 & 0 & 0 & 0 & 32 & 0 & $5.3 \pm 13.0$ \\
\hline & Harpacticoida & 0 & 16 & 0 & 0 & 0 & 0 & $2.7 \pm 6.5$ \\
\hline & Tanaidacea & 0 & 64 & 0 & 32 & 16 & 0 & $18.7 \pm 25.6$ \\
\hline & Cumacea & 0 & 0 & 0 & 16 & 0 & 0 & $2.7 \pm 6.5$ \\
\hline & Nematoda & 16 & 0 & 0 & 32 & 0 & 0 & $8.0 \pm 13.4$ \\
\hline & Gastropoda & 0 & 0 & 0 & 0 & 32 & 0 & $5.3 \pm 13.1$ \\
\hline & Ostracoda & 0 & 0 & 0 & 0 & 16 & 0 & $2.7 \pm 6.5$ \\
\hline Total & & 352 & 704 & 48 & 384 & 336 & 192 & $336 \pm 463.7$ \\
\hline
\end{tabular}


Table 3: Composition and abundance of macrofauna (mean nos. $\mathrm{m}^{-2}$ ) in CIB studied during INDEX (Post-disturbance) cruises.

\begin{tabular}{|c|c|c|c|c|c|c|c|c|c|c|c|c|c|c|c|c|c|}
\hline \multirow{2}{*}{$\begin{array}{l}\text { (Depth } \\
\text { (cms) }\end{array}$} & \multirow[t]{2}{*}{ Taxa } & \multicolumn{16}{|c|}{ Stations } \\
\hline & & 2 & 3 & 4 & 5 & 6 & 7 & 11 & 12 & 13 & 14 & 15 & 16 & 18 & 19 & 20 & Mean \pm sd \\
\hline \multirow[t]{6}{*}{$0-2$} & Polychaeta & 0 & 0 & 16 & 16 & 0 & 32 & 48 & 16 & 0 & 80 & 0 & 0 & 16 & 32 & 16 & $18.1 \pm 22.5$ \\
\hline & Harpacticoida & 0 & 0 & 48 & 0 & 32 & 16 & 32 & 32 & 16 & 48 & 0 & 0 & 80 & 0 & 16 & $21.3 \pm 23.9$ \\
\hline & Cumacea & 0 & 0 & 0 & 16 & 32 & 0 & 32 & 16 & 0 & 16 & 0 & 0 & 0 & 0 & 0 & $7.5 \pm 11.9$ \\
\hline & Nematoda & 0 & 32 & 32 & 0 & 128 & 32 & 48 & 16 & 16 & 16 & 0 & 32 & 64 & 0 & 48 & $30.9 \pm 33.3$ \\
\hline & Gastropoda & 0 & 0 & 64 & 0 & 0 & 32 & 0 & 0 & 48 & 0 & 0 & 0 & 0 & 0 & 0 & $9.6 \pm 20.7$ \\
\hline & Holothuroidea & 0 & 0 & 0 & 0 & 0 & 0 & 0 & 0 & 0 & 0 & 0 & 0 & 0 & 0 & 20 & $1.3 \pm 5.16$ \\
\hline \multirow[t]{7}{*}{$2--5$} & Polychaeta & 16 & 48 & 16 & 0 & 64 & 112 & 32 & 16 & 0 & 32 & 48 & 0 & 128 & 48 & 0 & $37.3 \pm 39.5$ \\
\hline & Harpacticoida & 0 & 32 & 0 & 0 & 48 & 48 & 16 & 0 & 0 & 0 & 32 & 0 & 224 & 112 & 0 & $34.1 \pm 61.0$ \\
\hline & Cumacea & 0 & 16 & 16 & 0 & 32 & 16 & 0 & 0 & 0 & 0 & 16 & 0 & 64 & 32 & 0 & $12.8 \pm 18.3$ \\
\hline & Nematoda & 0 & 80 & 144 & 32 & 16 & 96 & 64 & 0 & 32 & 32 & 16 & 16 & 128 & 48 & 0 & $46.9 \pm 46.2$ \\
\hline & Bivalvia & 0 & 16 & 0 & 0 & 16 & 0 & 0 & 0 & 16 & 0 & 0 & 0 & 32 & 16 & 0 & $6.4 \pm 10.1$ \\
\hline & Gastropoda & 0 & 0 & 0 & 0 & 0 & 0 & 0 & 32 & 0 & 0 & 0 & 0 & 32 & 0 & 0 & $4.2 \pm 11.2$ \\
\hline & Holothuroidea & 0 & 0 & 16 & 0 & 0 & 0 & 0 & 0 & 0 & 0 & 16 & 0 & 0 & 0 & 0 & $2.1 \pm 5.6$ \\
\hline \multirow[t]{6}{*}{$5-10$} & Polychaeta & 0 & 128 & 48 & 0 & 0 & 64 & 16 & 16 & 16 & 80 & 0 & 0 & 64 & 176 & 48 & $43.7 \pm 52.5$ \\
\hline & Harpacticoida & 0 & 32 & 0 & 0 & 0 & 16 & 0 & 0 & 0 & 16 & 0 & 32 & 16 & 32 & 32 & $11.7 \pm 14.1$ \\
\hline & Cumacea & 0 & 0 & 0 & 0 & 0 & 0 & 0 & 0 & 0 & 0 & 16 & 0 & 32 & 0 & 16 & $4.3 \pm 9.5$ \\
\hline & Nematoda & 0 & 32 & 32 & 0 & 16 & 48 & 32 & 48 & 48 & 48 & 16 & 16 & 128 & 96 & 16 & $38.4 \pm 34.6$ \\
\hline & Bivalvia & 0 & 32 & 64 & 0 & 0 & 0 & 0 & 0 & 0 & 0 & 0 & 48 & 64 & 32 & 0 & $16 \pm 24.9$ \\
\hline & Gastropoda & 0 & 0 & 0 & 0 & 0 & 0 & 0 & 48 & 0 & 0 & 0 & 0 & 0 & 0 & 0 & $3.2 \pm 12.4$ \\
\hline \multirow[t]{4}{*}{$10-20$} & Polychaeta & 0 & 32 & 0 & 32 & 0 & 0 & 0 & 0 & 0 & 0 & 0 & 0 & 0 & 32 & 0 & $6.4 \pm 13.2$ \\
\hline & Harpacticoida & 16 & 16 & 16 & 0 & 0 & 16 & 0 & 0 & 16 & 16 & 0 & 16 & 16 & 32 & 0 & $10.7 \pm 9.9$ \\
\hline & Cumacea & 0 & 0 & 0 & 0 & 0 & 0 & 16 & 0 & 16 & 16 & 0 & 0 & 16 & 0 & 0 & $4.3 \pm 7.3$ \\
\hline & Nematoda & 0 & 16 & 16 & 0 & 0 & 32 & 32 & 48 & 16 & 80 & 0 & 0 & 16 & 48 & 0 & $20.3 \pm 23.7$ \\
\hline Total & & 32 & 512 & 528 & 96 & 384 & 560 & 368 & 288 & 240 & 480 & 160 & 160 & 1120 & 736 & \begin{tabular}{|l|}
212 \\
\end{tabular} & $391.7 \pm 512.2$ \\
\hline
\end{tabular}


Table 4: Mean density (mean nos. per $\mathrm{m}^{2}$ ) and composition (\%) of major macrobenthic taxa in the sediment layer during preand post-disturbance study.

\begin{tabular}{|c|l|c|c|c|c|}
\hline \multirow{2}{*}{\begin{tabular}{c} 
Sediment $\begin{array}{c}\text { depth } \\
\text { (cms) }\end{array}$ \\
\cline { 2 - 6 }
\end{tabular}} & Taxon & \multicolumn{2}{|c|}{ Pre-disturbance } & \multicolumn{2}{c|}{ Post-disturbance } \\
\hline $0-2$ & Annelida & 149 & 44.5 & 49 & 12.4 \\
\hline & Crustacea & 48 & 14.3 & 29 & 7.34 \\
\hline & Mollusca & 0 & 0 & 10 & 2.53 \\
\hline & Holothuria & 0 & 0 & 2 & 0.51 \\
\hline & Sipunculida & 5 & 1.4 & 0 & 0 \\
\hline $2-5$ & Annelida & 24 & 7.1 & 84 & 21.27 \\
\hline & Crustacea & 11 & 3.3 & 47 & 11.9 \\
\hline & Mollusca & 0 & 0 & 11 & 2.8 \\
\hline & Holothuria & 0 & 0 & 2 & 0.5 \\
\hline $5-10$ & Annelida & 32 & 9.5 & 82 & 20.7 \\
\hline & Crustacea & 21 & 6.2 & 18 & 4.5 \\
\hline & Mollusca & 0 & 0 & 19 & 4.8 \\
\hline $10--20$ & Annelida & 13 & 3.9 & 27 & 6.8 \\
\hline & Crustacea & 27 & 8.0 & 15 & 3.8 \\
\hline & Mollusca & 5 & 1.5 & 0 & 0 \\
\hline
\end{tabular}


Figures:

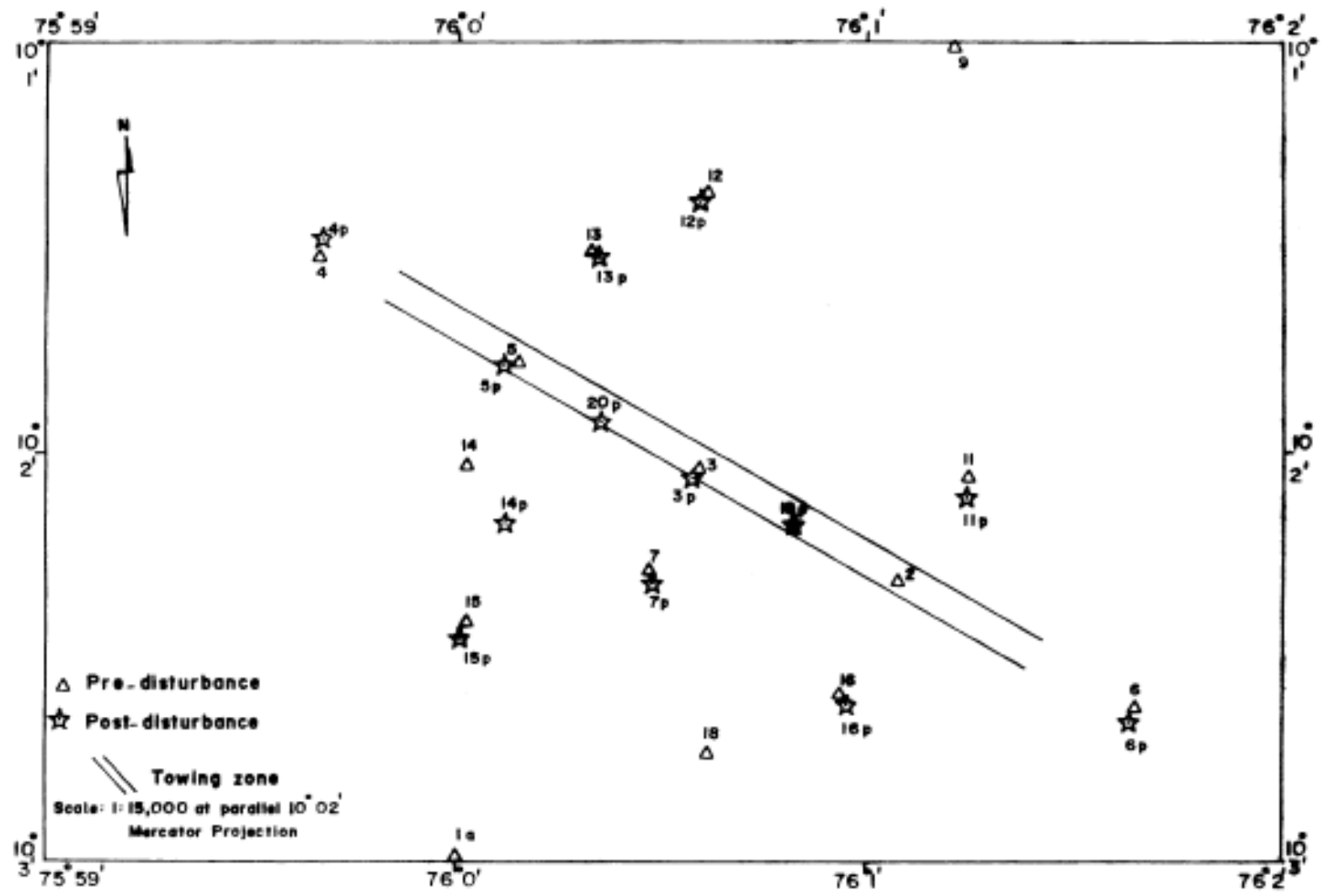

Figure 1: Location of the sampling stations.

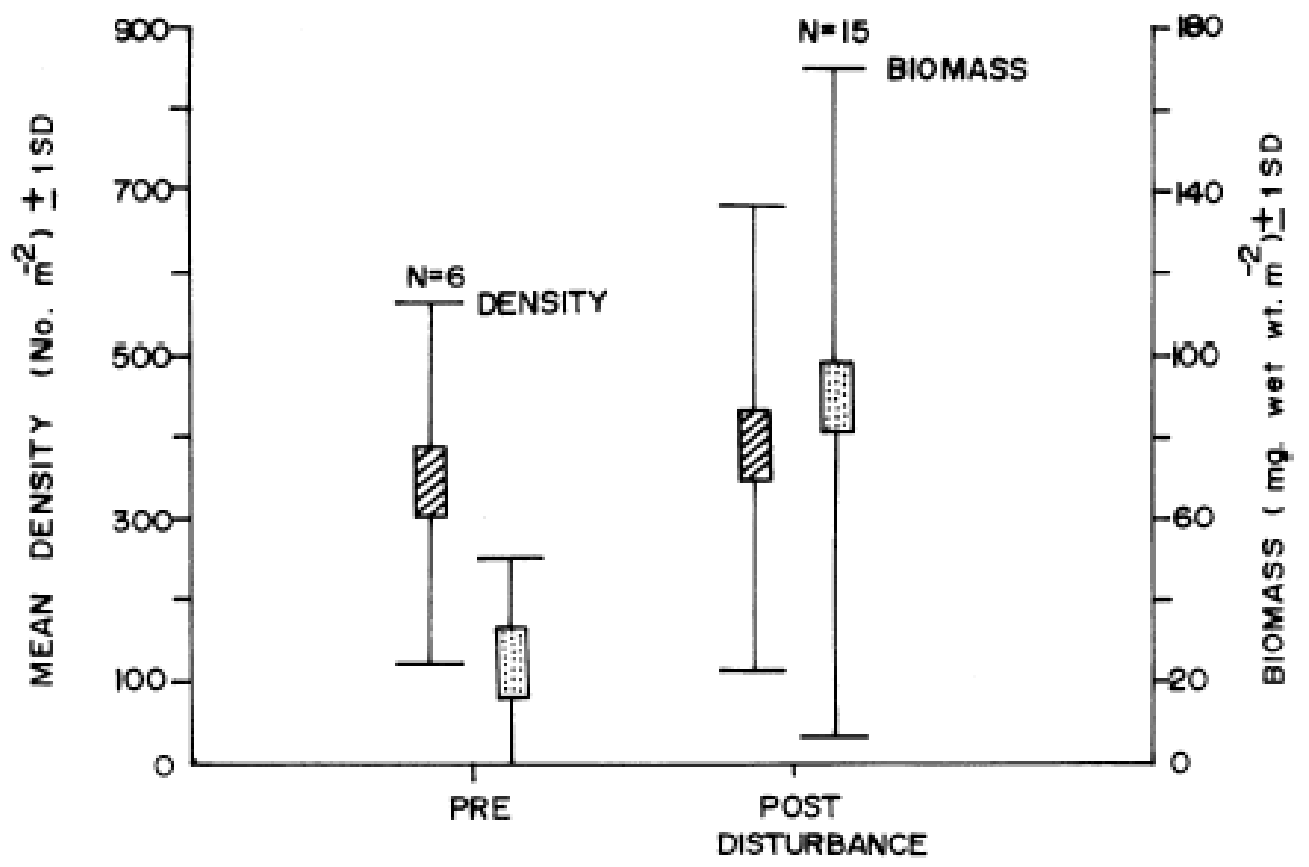

Figure 2: Mean density and biomass (vertical bar represents standard deviations) of macrobenthos pre- and post-disturbance study. 


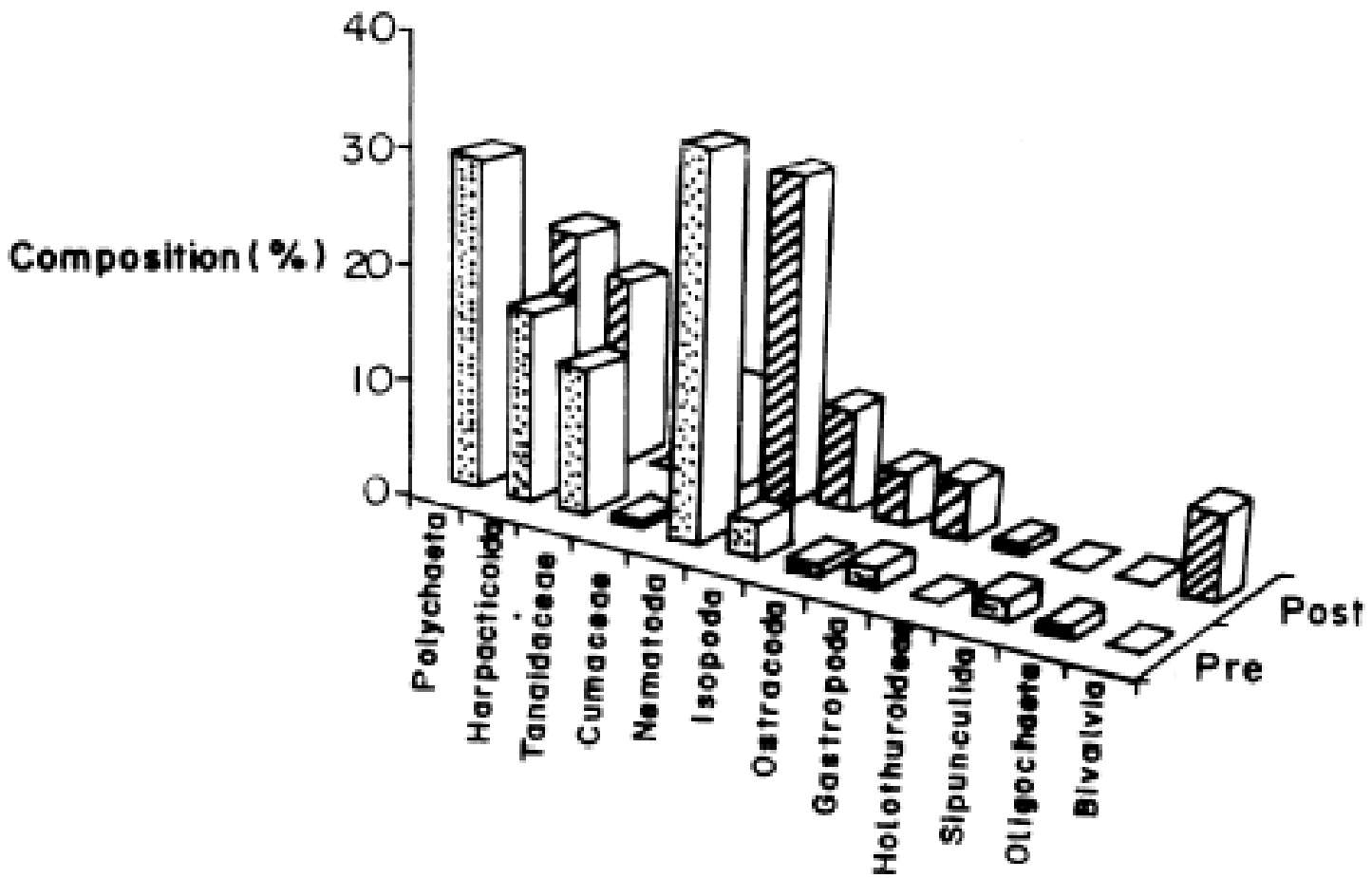

Figure 3: Abundance (no. per $\mathrm{m}^{2}$ ) of major macrofaunal groups during pre- and post-disturbance study.

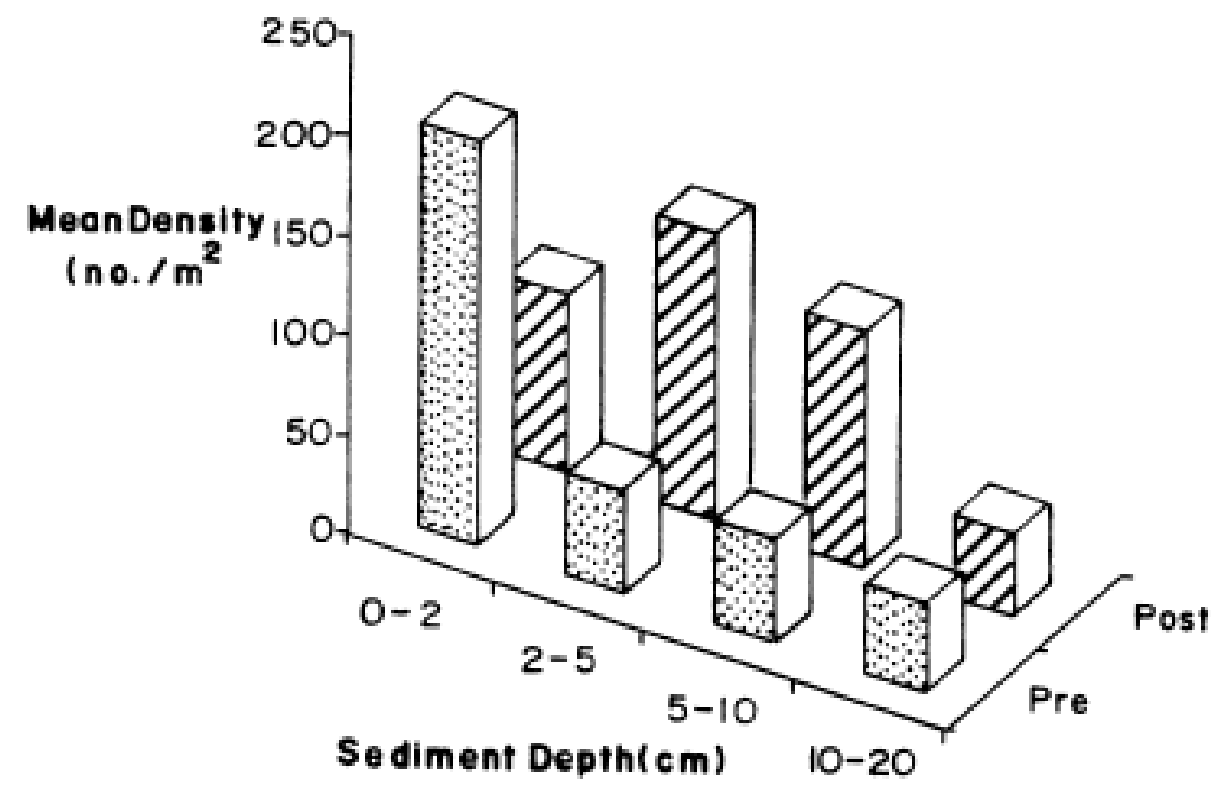

Figure 4: Vertical distribution of macrofauna during pre-\& post-disturbance study. 